\title{
42. HYDROGEOCHEMISTRY IN THE LAU BACKARC BASIN ${ }^{1}$
}

\author{
Gérard Blanc, ${ }^{2}$ Peter Stille, ${ }^{2}$ and Frédéric Vitali ${ }^{2}$
}

\begin{abstract}
Interstitial water samples from Sites 834 through 839, drilled during Ocean Drilling Program Leg 135 in the backarc Lau basin (Southwestern Pacific), have been analyzed for major elements, manganese, copper, strontium, barium, vanadium, and ${ }^{87} \mathrm{Sr}{ }^{86} \mathrm{Sr}$ isotopic composition values. The concentration-depth profiles of the major chemical components show almost straight concentration gradients at all sites, and seem to reflect slight alteration of volcanic material. However, in the lower part of the sedimentary cover, where volcanogenic material is abundant and where diagenetic minerals occur, systematic decreases in calcium, strontium, manganese, copper, and vanadium concentrations are observed. A downwelling flow of bottom seawater, which affected the diagenetic chemical signature of the interstitial water, is probably responsible for the recorded chemical features. This hypothesis is supported by strontium isotope data obtained from interstitial water samples at Site 835. It is also in accordance with data from heat flow and physical properties.
\end{abstract}

\section{INTRODUCTION}

The Lau basin is a typical example of an active backarc basin situated between a remnant (Lau Ridge) and an active (Tofua) volcanic arc. Hydrothermal activity and/or ore deposits in backarc environments have been previously described in the Okinawa (Halbach et al., 1989), Manus (Both et al., 1986), Mariana (Craig et al., 1987), and North Fiji (Auzende et al., 1989) basins. For the Lau basin, witnesses of hydrothermal activities have been observed in the northern part of the basin (Hawkins and Helu, 1986), at the Peggy Ridge (Bertine and Keene, 1975), and near the Valu Fa Ridge (von Stackelberg and Shipboard Scientific Party, 1985, 1988; von Stackelberg and von Rad, 1992; Fouquet and the Nautilau Group, 1990; Fouquet et al., 1991). Data obtained during the Nautilau diving cruise suggest that the Valu Fa Ridge is one of the most active hydrothermal areas of the oceans (Fouquet and the Nautilau Group, 1990). The metal contents $(\mathrm{Zn}, \mathrm{Cd}, \mathrm{As}, \mathrm{Pb})$ and the $\mathrm{pH}(\approx 2)$ are, respectively, the highest and the lowest ever measured in hydrothermal fields of oceanic ridges (Fouquet et al., 1991).

Leg 135 of the Ocean Drilling Program (ODP) drilled and cored six sites (Sites 834-839) located in the west of the Lau spreading centers (Central Lau [CLSC] and Eastern Lau [ELSC] spreading centers and Valu Fa Ridge [VF]; Fig. 1). These sites were drilled within smaller and narrower $(<10 \mathrm{~km})$ north-south fault basins and provide an ideal location to study fluid circulation and alteration of the interstitial water chemistry within a shallow sedimentary column situated at the flanks of the active spreading centers.

\section{SAMPLING AND ANALYTICAL PROCEDURES}

\section{Shipboard Analyses}

The shipboard analytical program for Leg 135 included analyses of interstitial water samples for $\mathrm{pH}$, alkalinity, salinity, $\mathrm{SO}_{4}^{2-}, \mathrm{Cl}^{-}$, $\mathrm{Ca}^{2+}, \mathrm{Mg}^{2+}, \mathrm{K}^{+}, \mathrm{Sr}^{2+}, \mathrm{H}_{4} \mathrm{SiO}_{4}, \mathrm{NH}_{4}^{+}, \mathrm{PO}_{4}^{3-}$ and $\mathrm{Mn}^{2+}$. The method for obtaining interstitial water from the sediment, using a stainless-steel squeezer, was described in detail by Manheim and Sayles (1974). For interstitial water analyses, 10-cm-long, whole-round sediment core samples were collected immediately after the core arrived on deck. The sediment was extruded from the core liner, the outer layer of the sediment was removed by scraping with a spatula, and the sample was

' Hawkins, J., Parson. L.. Allan. J., et al.. 1994. Proc. ODP, Sci. Results, 135: College Station. TX (Ocean Drilling Program).

${ }^{2}$ Centre de Sédimentologie et de Géochimie de la Surface, CNRS UPR no, 6251. Institut de Géologie Strasbourg (IGS), 1 rue Blessig. 67084 Strasbourg Cedex. France. placed in a Carver laboratory press to remove the interstitial water. The press operated at a pressure of about $30,000 \mathrm{psi}\left(2.11 \mathrm{~kg} / \mathrm{m}^{2}\right)$. The sediment remained under these pressure conditions until no more water could be squeezed out the sample. Interstitial water was collected in $50-\mathrm{cm}^{3}$ syringes and filtered with a $0.45-\mu \mathrm{m}$ Millipore filter. International Association for the Physical Sciences of the Ocean (IAPSO) standard seawater P99 was the primary standard for the water analysis on board. Individual inorganic species were analyzed according to procedures outlined by Gieskes and Peretsman (1986). Alkalinity and $\mathrm{pH}$ were determined using a Metrohm autotitrator with a Brinkmann combination $\mathrm{pH}$ electrode. Alkalinity reproducibility was better than $5 \%$; data are given in millimoles of acid equivalent per liter of solution. Salinity was determined using a Goldberg optical hand refractometer measuring the total dissolved solids. Chloride was measured by silver nitrate titration of a $0.1 \mathrm{~mL}$ sample diluted in $5 \mathrm{~mL}$ of deionized water using potassium chromate as an indicator. The reproducibility on different dilutions of the IAPSO standard is better than $\pm 1 \%$. Sulfate was quantified using a Dionex-2120 ion chromatograph. Reproducibility on different diluted aliquots of the IAPSO standard is better than $\pm 2 \%$. Calcium was determined by complexometric titration of a $0.5-\mathrm{cm}^{3} \mathrm{sam}$ ple with EGTA using GHA as an indicator. To enhance the determination of the end point, the calcium-GHA complex was extracted onto a butanol layer (Gieskes, 1973). Magnesium was determined by EDTA titration for total alkaline earth, and subsequent substraction of the calcium and strontium values yielded the magnesium concentration in the interstitial water sample. Ammonia, silica, and phosphate determinations were performed with a Gilford spectrophotometer as well as by means of the colorimetric methods described by Gieskes and Peretsman (1986).

Precisions of the analytical data generally are better than $2 \%$, but artefacts of squeezing may cause systematic offsets in the data. However, concentration-depth trends are not significantly affected. Atomic absorption measurements were performed using a Varian SpectrAA-20 spectrophotometer to determine $\mathrm{K}, \mathrm{Na}, \mathrm{Mg}, \mathrm{Sr}$, and $\mathrm{Mn}$. All measurements were done in absorption mode using an oxidizing air-acetylene flame. The relative precision for all these elements is lower than $5 \%$. Sodium concentrations were also determined by charge balance; the difference between the calculated and measured $\mathrm{Na}$ data never exceeded $5 \%$. Similar accuracies were obtained between the two methods of the $\mathrm{Mg}$ determination.

\section{Shore-based Analyses}

The shore-based analytical determinations of the interstitial water samples include dissolved trace elements and the strontium isotopic 


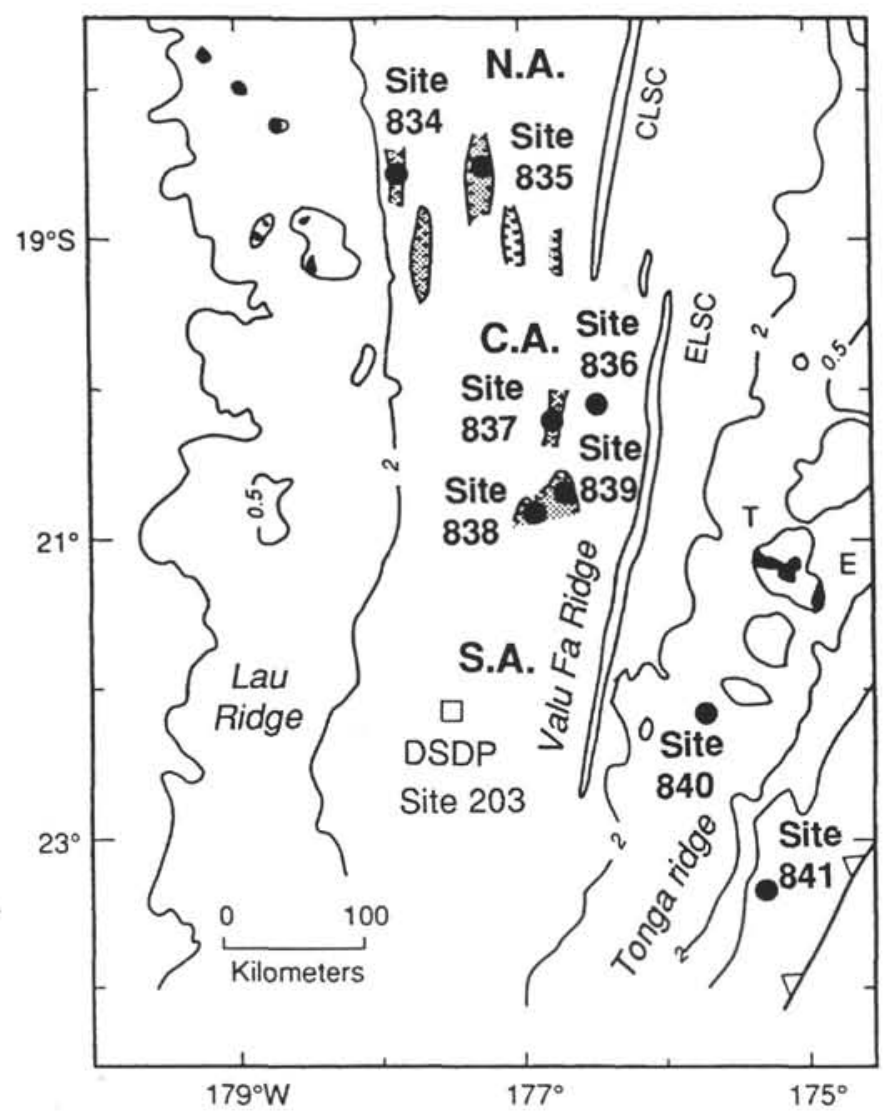

Figure 1. Map of backarc sites drilled in the Lau Basin during Leg 135 with bathymetry outlined ( 500 and 2000 isobaths). Known sub-basins are stippled. ELSC $=$ Eastern Lau Spreading Center. Contour intervals in kilometers. $\mathrm{T}=$ Tongatapu and $\mathrm{E}=$ 'Eua. From Parson, Hawkins, Allan, et al. (1992).

compositions. Determinations of $\mathrm{Si}, \mathrm{Mn}, \mathrm{Cu}, \mathrm{Ba}, \mathrm{V}, \mathrm{Zn}, \mathrm{Ni}, \mathrm{Co}, \mathrm{Cr}, \mathrm{Sc}$, $\mathrm{Y}$, and $\mathrm{Zr}$ were performed on interstitial water samples using an 35000 ARL inductively coupled plasma-atomic emission spectrometer (ICPAES). The interstitial water samples were diluted with MilliQ-dionized water acidified with $\mathrm{HNO}_{3}$. Dissolved $\mathrm{Zn}, \mathrm{Ni}, \mathrm{Co}, \mathrm{Cr}, \mathrm{Sc}, \mathrm{Y}$, and $\mathrm{Zr}$ concentrations were below the detection limits of the ICP-method $(\mathrm{Zn}$ $<40 \mathrm{ppb}, \mathrm{Ni}<40 \mathrm{ppb}, \mathrm{Co}<80 \mathrm{ppb}, \mathrm{Cr}<20 \mathrm{ppb}, \mathrm{Sc}<2 \mathrm{ppb}, \mathrm{Y}<4$ $\mathrm{ppb}$, and $\mathrm{Zr}<20 \mathrm{ppb}$ ). The general precision is between $2 \%$ and $5 \%$ for $\mathrm{Si}, \mathrm{Mn}, \mathrm{Cu}, \mathrm{Ba}$, and $\mathrm{V}$. The difference between shipboard and shore-based $\mathrm{Si}$ and $\mathrm{Mn}$ data never exceeded the analytical error of the methods. The elementary composition of the interstitial water samples is given in Table 1. Results are expressed in millimole or micromole per liter $(\mathrm{mM}$ or $\mu \mathrm{M})$.

The ${ }^{87} \mathrm{Sr} /{ }^{86} \mathrm{Sr}$ ratios were measured for Site 835 interstitial water samples using a VG Sector mass spectrometer. $\mathrm{A}^{87} \mathrm{Sr} /{ }^{86} \mathrm{Sr}$ value of $0.710266 \pm 0.000011(2 \sigma, N=18)$ was measured for the NBS 987 standard. The results are given in Table 2 .

\section{SITE DESCRIPTIONS AND RESULTS}

\section{Site 834}

The sedimentary sequence has been divided into four lithologic units, as follows.

Unit I, from 0 to $42 \mathrm{~m}$ below seafloor (mbsf), is essentially composed of clayey nannofossil ooze stained by iron-oxyhydroxide and sporadically interbedded with graded foraminiferal sands and oozes. Its age ranges from late Pleistocene to late Pliocene (2.6 Ma). Its average sedimentation rate is $18.2 \mathrm{~mm} / \mathrm{k} . \mathrm{y}$.
Unit II. from 42 to $78 \mathrm{mbsf}$, is late Pliocene in age and consists of clayey nannofossil ooze mixed sediment interbedded with vitric ash layers. Its clayey nannofossil ooze is more stained by iron-oxyhydroxide than that of Unit I. Downcore, foraminifers decrease whereas clay contents increase. The volcaniclastic sediment represents $20 \%$ of the total bulk sediment.

Unit III, from 78 to $112.5 \mathrm{mbsf}$, is early Pliocene in age and consists of up to $40 \%$ of vitric ashes interbedded with iron-oxyhydroxidestained nannofossil clayey mixed sediments and nannofossil clays.

Unit IV, from 131.5 to $162.6 \mathrm{mbsf}$, is primarily composed of indurated claystones, vitric tuffs, and calcarenites intercalated between vesicular basalt interpreted as a lava flow or sill.

Nine interstitial water samples were collected in Hole 834A. They were sampled from every core in the uppermost 55 mbsf. Below this depth, samples were taken only from every third core. One sample originates from the claystones of the Unit IV.

In Hole 834A, the concentration-depth profiles of the dissolved major constituents (chloride, sodium, calcium, magnesium, potassium, and sulfate) are characterized by fairly uniform values from the mud line to $135 \mathrm{mbsf}$ (Fig. 2). The $\mathrm{Na}^{+} / \mathrm{Cl}^{-}$ratios in all the interstitial water samples are constant (i.e., $0.857 \pm 0.005$ ). Calcium, magnesium, potas- sium, and sulfate concentrations determined in the interstitial water samples are almost equal to the average seawater concentration. The average concentration values from Hole $834 \mathrm{~A}$ are sulfate $=27.8$ $\pm 0.4 \mathrm{mM}$, calcium $=10.37 \pm 0.54 \mathrm{mM}$, magnesium $=52.3 \pm 1.07$ $\mathrm{mM}$, and potassium $=11.1 \pm 0.31 \mathrm{mM}$. The observed deviations from these concentrations do not exceed the analytical uncertainty of the analytical methods (Gieskes and Peretsman, 1986). These values are similar to the average concentrations in free seawater (e.g., 28, 10, 53 , and $11 \mathrm{mM}$, respectively: Broecker and Peng, 1982) and suggest that the elementary composition of the interstitial water is not affected by diagenetic processes. However, diagenetic processes are established by the occurrences of clays and zeolites (phillipsite, analcime) in this hole (Blanc, 1992, this volume). Hence, another mechanism must be involved to explain the uniform concentration values in dissolved major constituents.

Dissolved silica concentrations range between 200 and $400 \mu \mathrm{M}$, which is expected from sediments with little or no biogenic silica (Fig. 2 ). Because the influence of the squeezing effect dependent temperature on the dissolution of silica is not controlled, the absolute silica concentrations cannot be determined (Gieskes, 1973, 1974). However, relative changes in silica concentration may reflect changes in the mineralogical composition. Therefore, the slight increase in silica with depth is related to the increasing ash contents within the hole.

Concentrations of dissolved strontium gradually increase with depth to reach a maximum of about $130 \mathrm{mM}$ at $82 \mathrm{mbsf}$ (Fig. 2). Increasing strontium is generally related to carbonate recrystallization processes (Gieskes et al., 1986). However, in the lower part of Unit III and in Unit IV, a decrease in strontium concentrations is observed, even though calcarenite has been described for Unit IV.

Concentrations of dissolved barium and vanadium are very low and uniform throughout the sedimentary column, with respective average concentrations of $0.239 \pm 0.02 \mu \mathrm{M}$ and $0.652 \pm 0.07 \mu \mathrm{M}$.

In contrast to barium and vanadium, concentrations of dissolved manganese are not uniform along the sedimentary column (Fig. 2). From the mud line to $40 \mathrm{mbsf}$, manganese concentrations scatter around $40 \mu \mathrm{M}$. Between 40 and $50 \mathrm{mbsf}$, however, manganese concentrations increase up to more than $80 \mu \mathrm{M}$. These increased concentration values can be related to the occurrence of interbedded ash layers. Manganese concentrations decrease below $50 \mathrm{mbsf}$ and reach a value of only $0.4 \mathrm{mM}$ (Fig. 2). This decrease downhole cannot be explained by diagenetic processes.

From 5.9 to $32.5 \mathrm{mbsf}$, copper concentrations decrease from 5.98 to $1.13 \mu \mathrm{M}$. Copper release from a solid phase, like oxyhydroxides, may be responsible for the higher concentrations in the upper part of the hole. Another copper maximum reaching $3.18 \mu \mathrm{M}$ has been de- 
Table 1. Interstitial water data for major and minor constituents, Sites 834-839.

\begin{tabular}{|c|c|c|c|c|c|c|c|c|c|c|c|c|c|c|c|c|c|c|c|c|c|}
\hline $\begin{array}{l}\text { Core, section, } \\
\text { interval }(\mathrm{cm})\end{array}$ & $\begin{array}{l}\text { Depth } \\
\text { (mbsf) }\end{array}$ & $\mathrm{pH}$ & $\begin{array}{l}\text { Alkalinit } \\
(\mathrm{mM})\end{array}$ & $\begin{array}{l}\text { Salinity } \\
(\mathrm{mM})\end{array}$ & $\begin{array}{l}\mathrm{Ca}^{2+} \\
(\mathrm{mM})\end{array}$ & $\begin{array}{l}\text { TAE } \\
\mathrm{Mg}^{2+} \\
(\mathrm{mM})\end{array}$ & $\begin{array}{c}\mathrm{AA} \\
\mathrm{Mg}^{2+} \\
(\mathrm{mM})\end{array}$ & $\underset{(\mathrm{mM})}{\mathrm{K}^{+}}$ & $\begin{array}{l}\mathrm{MB} \\
\mathrm{Na}^{+} \\
(\mathrm{mM})\end{array}$ & $\begin{array}{c}\mathrm{AA} \\
\mathrm{Na}^{+} \\
(\mathrm{mM})\end{array}$ & $\underset{(\mathrm{mM})}{\mathrm{Cl}}$ & $\begin{array}{l}\mathrm{SO}_{4}^{2-} \\
(\mathrm{mM})\end{array}$ & $\begin{array}{l}\mathrm{NH}_{4}^{+} \\
(\mu \mathrm{M})\end{array}$ & $\begin{array}{l}\mathrm{PO}_{4}^{3-} \\
(\mu \mathrm{M})\end{array}$ & $\begin{array}{c}\mathrm{Si} \\
(\mu \mathrm{M})\end{array}$ & $\begin{array}{c}\mathrm{AA} \\
\mathrm{Mn}^{2+} \\
(\mu \mathrm{M})\end{array}$ & $\begin{array}{l}\text { ICP } \\
\mathrm{Mn}^{2+} \\
(\mu \mathrm{M})\end{array}$ & $\begin{array}{l}\mathrm{Sr}^{2+} \\
(\mu \mathrm{M})\end{array}$ & $\begin{array}{c}\mathrm{Cu} \\
(\mu \mathrm{M})\end{array}$ & $\begin{array}{c}\mathrm{Ba} \\
(\mu \mathrm{M})\end{array}$ & $\begin{array}{c}\mathrm{V} \\
(\mu \mathrm{M})\end{array}$ \\
\hline \multicolumn{22}{|l|}{$135-834 \mathrm{~A}-$} \\
\hline IH- $4,140-150$ & 5.9 & 7.75 & 3.04 & 35.2 & 9.8 & 51.7 & ND & 11.3 & 478 & ND & 558 & 27.63 & ND & ND & 263 & 43.3 & 42.6 & 115 & 5.98 & 0.25 & 0.69 \\
\hline $2 \mathrm{H}-4,140-150$ & 13.5 & 7.35 & 2.66 & 35.6 & 9.7 & 51.1 & ND & 11.5 & 487 & ND & 564 & 28.21 & ND & ND & 317 & 44.2 & 43.0 & 118 & 3.37 & 0.26 & 0.71 \\
\hline $3 \mathrm{H}-4,140-150$ & 23.0 & 7.73 & 2.56 & 35.2 & 10.2 & 53.1 & ND & 11.1 & 488 & ND & 571 & 27.89 & ND & ND & 357 & 41.6 & 45.9 & 115 & 1.75 & 0.20 & 0.53 \\
\hline $4 \mathrm{H}-4,140-150$ & 32.5 & 7.75 & 2.54 & 35.0 & 10.2 & 52.6 & ND & 11.0 & 488 & ND & 571 & 27.31 & ND & ND & 351 & 36.0 & 39.2 & 128 & 1.13 & 0.24 & 0.65 \\
\hline $5 \mathrm{H}-4,140-150$ & 42.0 & 7.71 & 2.36 & 35.8 & 10.5 & 53.3 & ND & 11.3 & 483 & ND & 567 & 27.58 & ND & ND & 337 & 90.7 & 88.5 & 127 & 1.42 & 0.22 & 0.61 \\
\hline $6 \mathrm{H}-4,140-150$ & 51.0 & 7.51 & 2.39 & 35.0 & 10.8 & 54.1 & ND & 11.4 & 486 & ND & 571 & 27.89 & ND & ND & 373 & 96.4 & 94.5 & 127 & 2.36 & 0.23 & 0.63 \\
\hline $9 \mathrm{H}-4,140-150$ & 80.0 & 7.68 & 2.37 & 35.2 & 11.3 & 51.7 & ND & 10.7 & 489 & ND & 569 & 28.58 & ND & ND & 379 & 70.9 & 67.5 & 130 & 3.18 & 0.27 & 0.75 \\
\hline $12 \mathrm{X}-1,140-150$ & 104.3 & 7.67 & 2.36 & 35.2 & 10.9 & 52.3 & ND & 11.0 & 489 & ND & 571 & 27.47 & ND & ND & 407 & $<10$ & 0.70 & 106 & 1.23 & 0.22 & 0.59 \\
\hline $16 \mathrm{X}-1,140-150$ & 133.3 & 8.16 & 2.44 & 35.3 & 10.0 & 50.9 & ND & 10.6 & 489 & ND & 565 & 28.00 & ND & ND & 369 & $<10$ & 0.40 & 81 & 1.12 & 0.26 & 0.71 \\
\hline \multicolumn{22}{|l|}{$\begin{array}{l}\text { 135-835A- } \\
\text { IH-4, 140-150 }\end{array}$} \\
\hline IH- $4,140-150$ & 6.0 & 7.61 & 3.11 & 35.4 & 10.5 & 51.6 & 49.2 & 11.2 & 471 & 475 & 550 & 27.9 & 9 & 2.9 & 317 & 24.5 & 23.3 & 97 & 1.92 & 0.22 & 0.81 \\
\hline $2 \mathrm{H}-4,140-150$ & 15.5 & 7.51 & 2.56 & 35.4 & 10.9 & 51.7 & 50.8 & 11.2 & 474 & 475 & 554 & 28.1 & 11 & 2.7 & 354 & 40.7 & 39.6 & 103 & 2.74 & 0.25 & 0.86 \\
\hline $3 \mathrm{H}-4,140-150$ & 25.0 & 7.62 & 2.24 & 35.6 & 10.8 & 52.5 & 52.4 & 11.6 & 471 & 471 & 553 & 28.4 & 19 & 2.4 & 312 & 49.1 & 45.4 & 102 & 2.80 & 0.25 & 1.08 \\
\hline $4 \mathrm{H}-4,140-150$ & 34.0 & 7.68 & 2.27 & 35.8 & 11.1 & 52.0 & 51.2 & 11.1 & 472 & 474 & 554 & 27.7 & 26 & 1.5 & 317 & 56.7 & 54.5 & 99 & 3.18 & 0.25 & 1.08 \\
\hline $6 \mathrm{H}-4,140-150$ & 53.5 & 7.59 & 2.27 & 35.9 & 11.3 & 51.1 & 50.6 & 11.3 & 472 & 473 & 552 & 27.1 & 62 & 2.0 & 342 & 84.2 & 78.2 & 104 & 2.69 & 0.28 & 1.22 \\
\hline $8 \mathrm{H}-4,140-150$ & 72.5 & 7.50 & 2.65 & 35.6 & 11.7 & 52.1 & 49.8 & 10.7 & 469 & 473 & 553 & 26.8 & 39 & 2.3 & 342 & 102.2 & 97.3 & 111 & 2.08 & 0.28 & 1.33 \\
\hline $10 \mathrm{H}-4,140-150$ & 91.5 & 7.50 & 2.76 & 35.6 & 12.3 & 50.5 & 50.8 & 10.8 & 470 & 469 & 551 & 27.1 & 34 & 3.0 & 354 & 108.7 & 104 & 122 & 2.17 & 0.28 & 1.33 \\
\hline $12 \mathrm{H}-4,140-150$ & 110.5 & 7.13 & 2.76 & 35.6 & 12.9 & 51.7 & 51.6 & 10.3 & 465 & 466 & 551 & 26.4 & 24 & 3.4 & 371 & 134.2 & 127 & 124 & 2.27 & 0.26 & 1.53 \\
\hline $14 \mathrm{H}-4,140-150$ & 129.5 & 7.52 & 2.55 & 35.3 & 12.7 & 51.7 & 50.4 & 10.5 & 465 & 468 & 551 & 26.7 & 19 & 3.5 & 388 & 100.2 & 96.9 & 122 & 2.11 & 0.28 & 1.57 \\
\hline $16 \times-6.140-150$ & 148.5 & 7.58 & 2.44 & 35.5 & 11.3 & 49.3 & 49.2 & 11.4 & 469 & 469 & 548 & 26.7 & 19 & 3.5 & 438 & 33.1 & 30.6 & 118 & 1.62 & 0.27 & 1.89 \\
\hline \multicolumn{22}{|l|}{$135-836 \mathrm{~A}-$} \\
\hline $2 \mathrm{H}-4,140-150$ & 7.2 & 7.71 & 3.09 & 35.4 & 10.8 & 52.4 & 52.7 & 11.2 & 468 & 467 & 549 & 27.8 & 17 & 3.6 & 290 & $<10$ & 6.1 & 99 & 1.95 & 0.24 & 1.53 \\
\hline $3 \mathrm{H}-5,140-150$ & 16.7 & 7,49 & 2.38 & 35.0 & 10.3 & 51.9 & 52.6 & 11.6 & 468 & 467 & 548 & 28.0 & 42 & 2.4 & 288 & $<10$ & 0.9 & 104 & 1.83 & 0.24 & 1.49 \\
\hline \multicolumn{22}{|l|}{$135-837 \mathrm{~A}-$} \\
\hline $1 \mathrm{H}-3,140-150$ & 4.5 & 7.59 & 3.38 & 34.7 & 10.3 & 52.7 & 54.7 & 11.6 & 465 & 463 & 545 & 28.9 & 8 & 4.8 & 278 & 27.4 & 25.5 & 101 & 2.71 & 0.26 & 1.37 \\
\hline $2 \mathrm{H}-4,140-150$ & 14.0 & 7.59 & 2.95 & 35.0 & 10.1 & 52.5 & 53.8 & 10.9 & 471 & 469 & 549 & 29.3 & 9 & 3.1 & 289 & 28.4 & 26.1 & 97 & 2.30 & 0.25 & 1.84 \\
\hline $3 \mathrm{H}-4,140-150$ & 23.5 & 7.45 & 2.75 & 35.8 & 10.2 & 52.0 & 53.0 & 10.8 & 475 & 473 & 552 & 29.0 & 5 & 2.3 & 305 & 55.8 & 52.2 & 98 & 1.75 & 0.26 & 1.69 \\
\hline $4 \mathrm{H}-4,140-150$ & 31.5 & 7.97 & 3.03 & 35.8 & 10.8 & 54.0 & 55.2 & 9.8 & 473 & 471 & 553 & 29.8 & 8 & 1.2 & 295 & 52.0 & 49.9 & 110 & 3.24 & 0.26 & 2.08 \\
\hline $6 \mathrm{H}-4,140-150$ & 53.5 & 7.68 & 2.59 & 34.2 & 10.1 & 52.2 & 52.6 & 11.9 & 475 & 474 & 554 & 28.9 & 6 & 2.6 & 320 & 70.9 & 67.1 & 107 & 2.00 & 0.25 & 1.57 \\
\hline $8 \mathrm{H}-4,140-150$ & 71.0 & 7.82 & 2.52 & 36.0 & 10.2 & 52.9 & 53.1 & 11.8 & 476 & 474 & 555 & 29.6 & 9 & 2.4 & 311 & 87.0 & 85.1 & 101 & 1.48 & 0.24 & 1.53 \\
\hline \multicolumn{22}{|l|}{$135-838 \mathrm{~A}-$} \\
\hline $2 \mathrm{H}-4,140-150$ & 9.0 & 7.58 & 2.59 & 35.2 & 10.5 & 53.8 & ND & 11.6 & 464 & ND & 548 & 27.9 & 15 & 2.7 & 291 & 23.2 & 24.5 & 98 & 3.78 & 0.18 & 1.35 \\
\hline $3 \mathrm{H}-4,140-150$ & 19.0 & 7.44 & 2.94 & 35.2 & 11.6 & 52.7 & ND & 9.8 & 466 & ND & 548 & 28.4 & 15 & 2.2 & 358 & 55.3 & 54.5 & 102 & 2.72 & 0.20 & 1.00 \\
\hline $4 \mathrm{H}-4,140-150$ & 28.7 & 7.37 & 2.96 & 35.5 & 13.5 & 50.3 & ND & 10.4 & 467 & ND & 551 & 28.1 & 16 & 2.0 & 610 & 49.2 & 50.9 & 100 & 3.21 & 0.21 & 1.34 \\
\hline $8 \mathrm{H}-4,140-150$ & 66.7 & 7.52 & 3.08 & 35.8 & 15.0 & 49.0 & ND & 9.2 & 470 & ND & 553 & 28.9 & 16 & 1.6 & 608 & 54.3 & 52.4 & 97 & 2.41 & 0.22 & 1.37 \\
\hline \multicolumn{22}{|l|}{$135-839 \mathrm{~A}-$} \\
\hline $1 \mathrm{H}-2,140-150$ & 3.0 & 7.62 & 3.18 & 35.6 & 10.5 & 53.7 & ND & 10.8 & 465 & ND & 548 & 27.5 & 16 & 5.7 & 316 & 45.9 & 46.4 & 103 & 1.91 & 0.20 & 1.88 \\
\hline $2 \mathrm{H}-4,140-150$ & 10.5 & 7.44 & 3.00 & 35.5 & 10.3 & 53.8 & ND & 11.5 & 464 & ND & 549 & 28.5 & 15 & 2.8 & 345 & 54.8 & 56.9 & 101 & 1.66 & 0.21 & 1.59 \\
\hline $3 \mathrm{H}-4,140-150$ & 20.0 & 7.61 & 2.96 & 35.3 & 10.5 & 53.6 & ND & 9.9 & 467 & ND & 549 & 28.1 & 17 & 2.1 & 289 & 56.3 & 58.2 & 99 & 1.31 & 0.21 & 1.88 \\
\hline $4 \mathrm{H}-4,140-150$ & 31.0 & 7.53 & 2.94 & 35.4 & 10.4 & 53.7 & ND & 10.2 & 466 & ND & 550 & 27.3 & 18 & 2.3 & 405 & 65.9 & 68.8 & 101 & 1.83 & 0.22 & 1.75 \\
\hline $6 \mathrm{H}-4,140-150$ & 48.5 & 7.86 & 3.12 & 35.5 & 10.4 & 53.8 & ND & 11.5 & 465 & ND & 554 & 28.7 & 18 & 1.4 & 339 & 87.9 & 85.6 & 100 & 3.12 & 0.23 & 2.16 \\
\hline $8 \mathrm{H}-4,140-150$ & 67.5 & 7.94 & 3.04 & 36.0 & 10.6 & 53.9 & ND & 10.3 & 465 & ND & 546 & 28.4 & 23 & 1.1 & 357 & 51.6 & 50.3 & 93 & 2.72 & 0.23 & 1.79 \\
\hline $10 \mathrm{H}-5,140-150$ & 88.0 & 7.66 & 2.37 & 35.5 & 10.3 & 50.7 & ND & 11.6 & 468 & ND & 547 & 27.2 & 20 & 1.9 & 339 & 20.6 & 22.0 & 97 & 1.68 & 0.23 & 1.90 \\
\hline
\end{tabular}

Notes: $\mathrm{TAE}=$ total alkaline earth, $\mathrm{AA}=$ atomic absorption, $\mathrm{MB}=$ mass balance, and $\mathrm{ICP}=$ inductively coupled plasma-atomic emission spectrometer $\mathrm{ND}=$ not determined.

tected at 80.0 mbsf. Below this depth, the copper concentration-depth profile shows the same trend as that of manganese and strontium.

\section{Site 835}

The sedimentary sequence recovered was divided into two units, as follows.

Unit I, from 0 to $130 \mathrm{mbsf}$, consists of iron-oxyhydroxide-stained, clayey nannofossil ooze with sporadic interbeds of thin vitric volcanic silts, thin foraminifer sands, foraminifer nannofossil oozes, and thick mud-clast conglomerates. Vitric volcanic silty layers are present, particularly within the intervals $35-55$ and $70-75 \mathrm{mbsf}$, although volcaniclastic material is only rare in the sediment column between 75 and 130 mbsf.

Unit II, from 130 to $155.1 \mathrm{mbsf}$, is composed of clayey nannofossil mixed sediments interbedded with epiclastic vitric ash layers and

Table 2. Strontium isotope data, Site 835.

\begin{tabular}{crc}
\hline $\begin{array}{c}\text { Core, section, } \\
\text { interval (cm) }\end{array}$ & $\begin{array}{r}\text { Depth } \\
\text { (mbsf) }\end{array}$ & ${ }^{87} \mathrm{Sr} /{ }^{86} \mathrm{Sr}$ \\
\hline $135-835 \mathrm{~A}-$ & & \\
$1 \mathrm{H}-4,140-150$ & 6.0 & $0.709155 \pm 0.000006$ \\
$3 \mathrm{H}-4,140-150$ & 25.0 & $0.709094 \pm 0.000004$ \\
$8 \mathrm{H}-4,140-150$ & 72.5 & $0.709045 \pm 0.000006$ \\
$12 \mathrm{H}-4,140-150$ & 110.5 & $0.709045 \pm 0.000006$ \\
$14 \mathrm{H}-4,140-150$ & 129.5 & $0.708990 \pm 0.000005$ \\
$16 \mathrm{H}-6,140-150$ & 148.5 & $0.709156 \pm 0.000006$ \\
\hline
\end{tabular}

volcanic silts, and is characterized by a content in volcanic material, especially glass, higher than that of Unit I.

Below $155.1 \mathrm{mbsf}$, vesicular basalts were cored.

A total of 10 interstitial water samples was collected. They were retrieved in the uppermost $35 \mathrm{mbsf}$ from every core. Below this depth, interstitial water samples were only taken every second core.

The concentration-depth profiles of the dissolved major constituents (chloride, sodium, calcium, magnesium, potassium, and sulfate) are characterized by fairly uniform values from the mud line to the bottom of the sedimentary column (Fig. 3 ). This result is identical to that obtained in Hole 834A.

Phosphate and ammonia are metabolic decompositional products of organic matter. The enrichment in ammonia concentration at 53.5 mbsf $(62 \mu \mathrm{M})$ and the depletion in phosphate at $34 \mathrm{mbsf}(1.5 \mu \mathrm{M})$ could be the result of phosphate uptake into newly formed mineral phases during diagenesis leading to a phosphate depletion in the interstitial waters. Nevertheless, the dissolved ammonia and phosphate concentrations are very low, which is consistent with the almost straight sulfate concentration gradient in this hole. The low production of ammonia could also be derived from processes involving anaerobic respiration (carbonate reduction) or fermentation (Claypool and Kaplan, 1974). Such processes are consistent with the high $\mathrm{CO}_{2}$ gas level observed in Section 135-835A-6R-5 (Parson, Hawkins, Allan, et al., 1992). The decrease in ammonia below $53.5 \mathrm{mbsf}$ could be related to clay uptake (Rosenfeld, 1979; von Breymann and Suess, 1988).

The barium concentration-depth profile is uniform in value over the whole profile (average $=0.262 \pm 0.02 \mu \mathrm{M}$ ). The increase in vanadium concentrations downhole is probably related to the increas- 

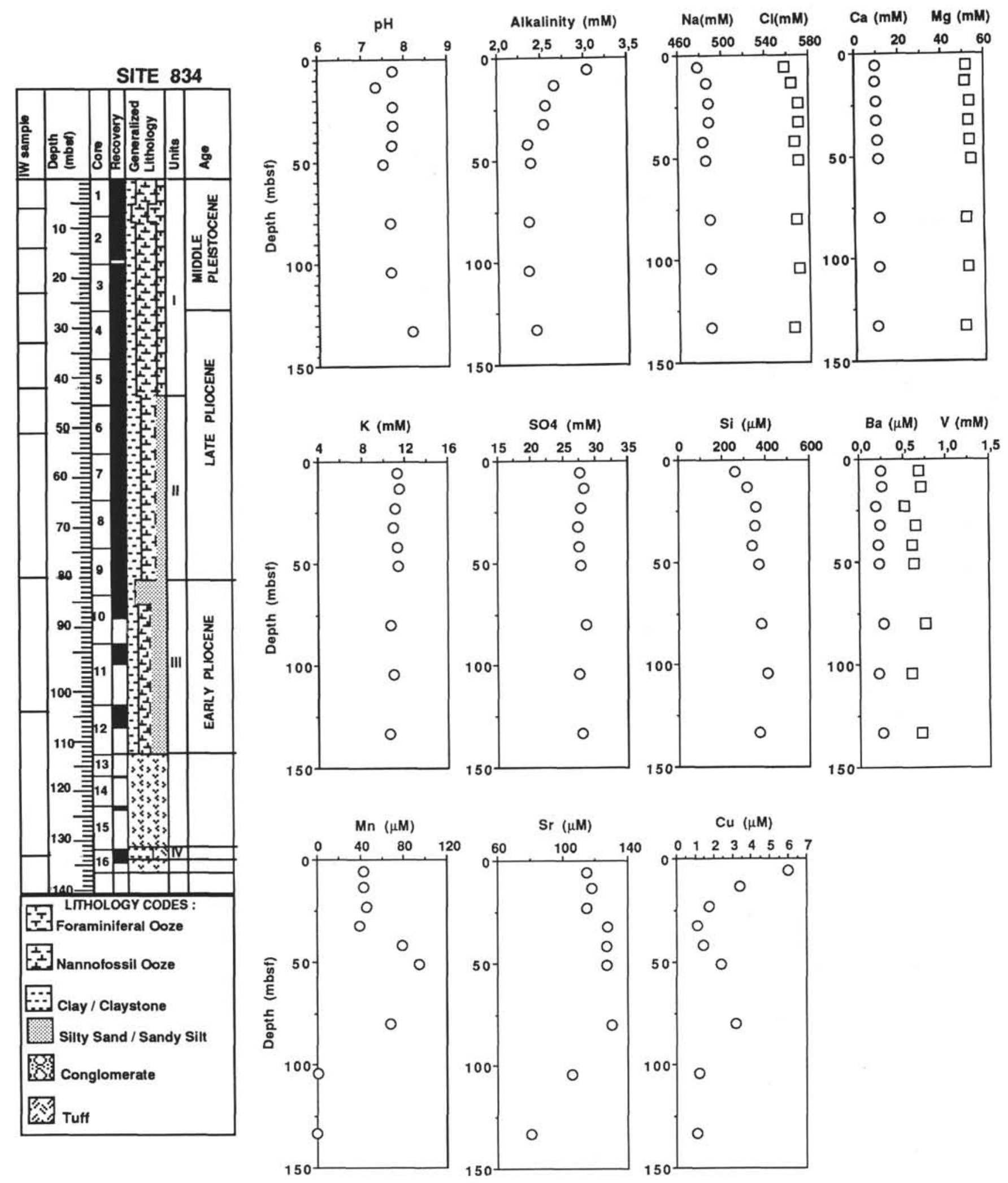

Figure 2. Lithologic summary column and interstitial water chemistry, Site 834 . 


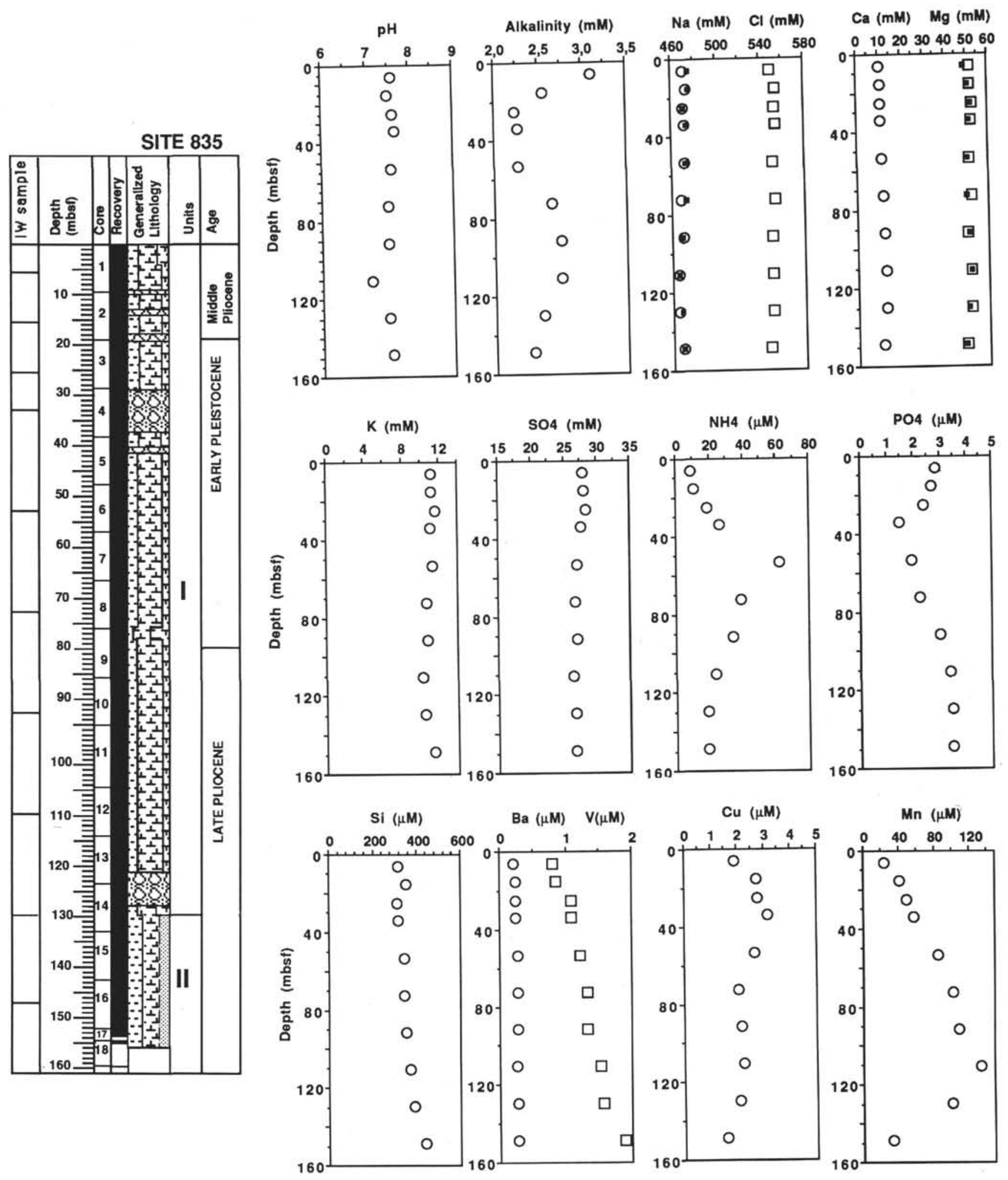

Figure 3. Lithologic summary column and interstitial water chemistry, Site 835.

ing portion of volcanic material. The values of the dissolved silica concentrations in Hole 835A are comparable to those obtained at Site 834 (Fig. 3). The manganese concentration-depth profile shows an almost linear increase with depth. Below $110.5 \mathrm{mbsf}$, a linear decrease is observed. The concentration maximum of manganese $(134.2 \mu \mathrm{M}$ at $1(0.5 \mathrm{mbsf})$ implies a release of manganese from solid phases. A copper maximum of about $3.18 \mu \mathrm{M}$ is reached at $34 \mathrm{mbsf}$ in the weathered, pumice-rich, mud-clast conglomerate layer. Enhanced copper concentrations were not detected at the base of Unit I, where another thick layer of pumice-bearing conglomerates has been observed. Furthermore, dissolved copper concentrations decrease in Unit II, whereas the volcanic glass content increases drastically. 


\section{Site 836}

A lithostratigraphic unit of $21 \mathrm{~m}$ thickness overlies vesicular basalt breccia. This unit comprises a sequence of generally thick-bedded, clayey nannofossil oozes with interbeds of volcaniclastic sediment. The hemipelagic deposits of Subunit IA contain up to $25 \mathrm{vol} \%$ of dispersed glass shards and are separated by rare ash layers. In Subunit IB, the number of volcaniclastic layers increases markedly. The sediments are middle to late Pleistocene in age. Only two interstitial water samples were collected. They show the same chemical characteristics as those obtained for Holes $834 \mathrm{~A}$ and $835 \mathrm{~A}$.

\section{Site 837}

The 82.1-m-thick sedimentary sequence consists of clayey nannofossil ooze and vitric volcaniclastic rocks ranging in age from the Holocene to the late Pliocene. It was divided in two lithologic units.

Unit I, from 0 to $13.5 \mathrm{mbsf}$, is of Holocene to middle Pleistocene age $(0.5-0.6 \mathrm{Ma})$. The sedimentation rate is about $25 \mathrm{~mm} / \mathrm{k} . \mathrm{y}$. and is composed of iron-oxyhydroxide-stained, clayey nannofossil ooze containing rare beds of graded foraminifer oozes and thin vitric silts.

Unit II, from 13.5 to $82.1 \mathrm{mbsf}$, is of middle Pleistocene to late Pliocene age. The average sedimentation rate is about $38 \mathrm{~mm} / \mathrm{k} . \mathrm{y}$. It consists of thick volcaniclastic sands and silts interbedded with clayey nannofossil ooze.

Below 82.1 mbsf, igneous rocks were recovered.

Six interstitial water samples were collected from Hole 837A. They were collected from every core in the uppermost $32 \mathrm{mbsf}$; below this depth, samples were taken from every second core.

The chemical data in Hole 837A are comparable with those obtained in Holes 834A, 835A, and 836A (Fig. 4). Comparison between the low and uniform ammonia concentrations and the scatter of phosphate concentrations indicates that only small amounts of phosphate are released by organic matter degradation. The manganese concentration-depth profile at Site 837 shows a regular increase of manganese with depth. The manganese maximum reaches a value of about $87 \mu \mathrm{M}$ at $71 \mathrm{mbsf}$. Slight decreases in strontium, copper, and vanadium are observed in the lower part of this hole.

\section{Site 838}

The sedimentary sequence consists of $98.7 \mathrm{~m}$ of volcaniclastic sediments and clayey nannofossil ooze, ranging in age from the middle Pleistocene to the upper Pliocene. It was divided into two lithologic units.

Unit I, from 0 to $23.04 \mathrm{mbsf}$, is of early to middle Pleistocene age $(0.02-1.44 \mathrm{Ma})$. An average sedimentation rate of $21 \mathrm{~mm} / \mathrm{k} . \mathrm{y}$. can be calculated. It is composed of homogeneous iron-oxyhydroxide-stained, clayey nannofossil oozes interbedded by four volcaniclastic layers.

Unit II, from 23.04 to $98.7 \mathrm{mbsf}$, is of late Pliocene to early Pleistocene age (1.4-1.9 Ma). An average sedimentation rate of 47 $\mathrm{mm} / \mathrm{k}$.y. can be calculated for the sedimentary column between 23.04 and $55 \mathrm{mbsf}$, and an average rate of $177 \mathrm{~mm} / \mathrm{k} . \mathrm{y}$. for the sediments accumulated between 55 and $98.7 \mathrm{mbsf}$. This unit is dominated by very thick (up to $20 \mathrm{~m}$ ), massive vitric sands and silts, and pumiceous gravels.

At 98.7 to 260 mbsf, indurated volcanic sediments were recovered.

Only four interstitial water samples were collected in Hole 838A; three of them were sampled in the uppermost $32 \mathrm{mbsf}$ of clayey nannofossil ooze and the fourth was collected from an interbedded clayey nannofossil ooze layer within the volcanic turbidites.

In Hole $838 \mathrm{~A}$, interstitial water chloride, sodium, sulfate, and strontium concentrations are indistinguishable from the concentrations of average seawater (Fig. 5).

Values of dissolved ammonia and phosphate concentrations in Hole $838 \mathrm{~A}$ interstitial waters are comparable with those obtained in samples from the other Leg 135 sites drilled in the Lau Basin and are consistent with the sulfate data (Fig. 5).
The concentration-depth profiles of dissolved calcium and magnesium show slight deviations from average seawater compositions with increasing depth (Fig. 5). From the mud line to $67 \mathrm{mbsf}$, these deviations include a relative depletion in magnesium concentration of about $-4.4 \mathrm{mM}$ and a relative increase in calcium concentration of about $+4.5 \mathrm{mM}$. These variations are greater than the analytical error, and linearly correlated concentration changes occur in calcium and magnesium. These changes follow the relationship $\Delta \mathrm{Ca} / \Delta \mathrm{Mg}=-0.94$ \pm 0.09 (the $\Delta$ concentration used is $\Delta=$ interstitial water concentration - standard sea water concentration). A linear $\Delta \mathrm{Ca}$ vs. $\Delta \mathrm{Mg}$ correlation implies conservative behavior for these elements, at least over the thickness of the sedimentary column studied (McDuff, 1981). The observed changes of calcium and magnesium in the interstitial waters might be the result of exchange by diffusion with the underlying and alternating Layer 2 of the oceanic crust, as suggested for many other DSDP/ODP sites (Gieskes et al., 1975; Kastner and Gieskes, 1976; McDuff and Gieskes, 1976; Gieskes and Lawrence, 1981). The absence of a sulfate concentration gradient suggests that the slight increase in alkalinity with depth is independent of the bacterially mediated sulfate reduction (Fig. 5). Downhole temperatures between 30 and 70 mbsf (ranging from $2.5^{\circ}$ to $6^{\circ} \mathrm{C}$ ) are probably too low to consider the volcanic turbidites as the source for calcium and as the sink for magnesium. However, volcaniclastic sediments poorly recovered below $98 \mathrm{mbsf}$ suggest that vitric silts and gravel may dominate the sequence at least at the base of the core section ( $260 \mathrm{mbsf}$ ). In this case, diagenetic processes involving the alteration of volcanic materials of this sedimentary sequence could contribute to calcium release and magnesium uptake.

The nature of the dissolved potassium profile (Fig. 5) implies an almost linear $\Delta \mathrm{Ca} / \Delta \mathrm{K}$ relationship and is probably also related to the alteration of volcanic material of the upper oceanic crust and of the base of the sedimentary column.

Dissolved silica concentrations increase gradually with depth to reach a maximum value of about $610 \mu \mathrm{M}$ at $28.7 \mathrm{mbsf}$ (Fig. 5). The increase in silica with depth, therefore, could be related to the occurrence of thick vitric sand and gravel layers characteristic for this hole. Below this depth, silica concentration remains constant, although volcanic material is the major component in the sedimentary column. This can be explained by dilution of the silica concentration toward the bottom of the hole.

The concentrations of copper, barium, and vanadium measured in this hole are comparable with those determined for the holes described previously.

The manganese concentration-depth profile for Hole 838A (Fig. 5) shows an increase with depth. The manganese maximum (about 55 $\mu \mathrm{M}$ ) was reached at $19 \mathrm{mbsf}$ in the upper nannofossil ooze unit and, as mentioned for the previously studied holes, suggests a release of manganese during diagenetic processes. Below this depth, a slight decrease is observed in the vicinity of the volcanic turbidite unit. Manganese concentrations decrease to low values near the boundary between hemipelagic sediments and basalts and within volcaniclastic sediments. This general pattern was also observed in Holes 834A through 836A.

\section{Site 839}

The sedimentary sequence ranges in age from the middle Pleistocene to the late Pliocene. It was divided into two lithologic units.

Unit I, from 0 to $17.85 \mathrm{mbsf}$, is of middle Pleistocene age. An average sedimentation rate of $9 \mathrm{~mm} / \mathrm{k} . \mathrm{y}$. can be deduced. It is composed of iron-oxyhydroxide-stained, clayey nannofossil ooze containing rare volcaniclastic ash layers.

Unit II, from 17.85 to $99.5 \mathrm{mbsf}$, is of middle Pleistocene to late Pliocene age. An average sedimentation rate of $51 \mathrm{~mm} / \mathrm{k} . \mathrm{y}$. has been calculated. In comparison with Unit I, Unit II shows much higher contents in volcaniclastic material.

From 99.5 to $214 \mathrm{mbsf}$, volcanic indurated sediments were poorly recovered, and $10 \mathrm{~m}$ of intralava sediments were recovered between 256.7 and 266.7 mbsf in Hole 839B. 
HYDROGEOCHEMISTRY IN LAU BACKARC BASIN

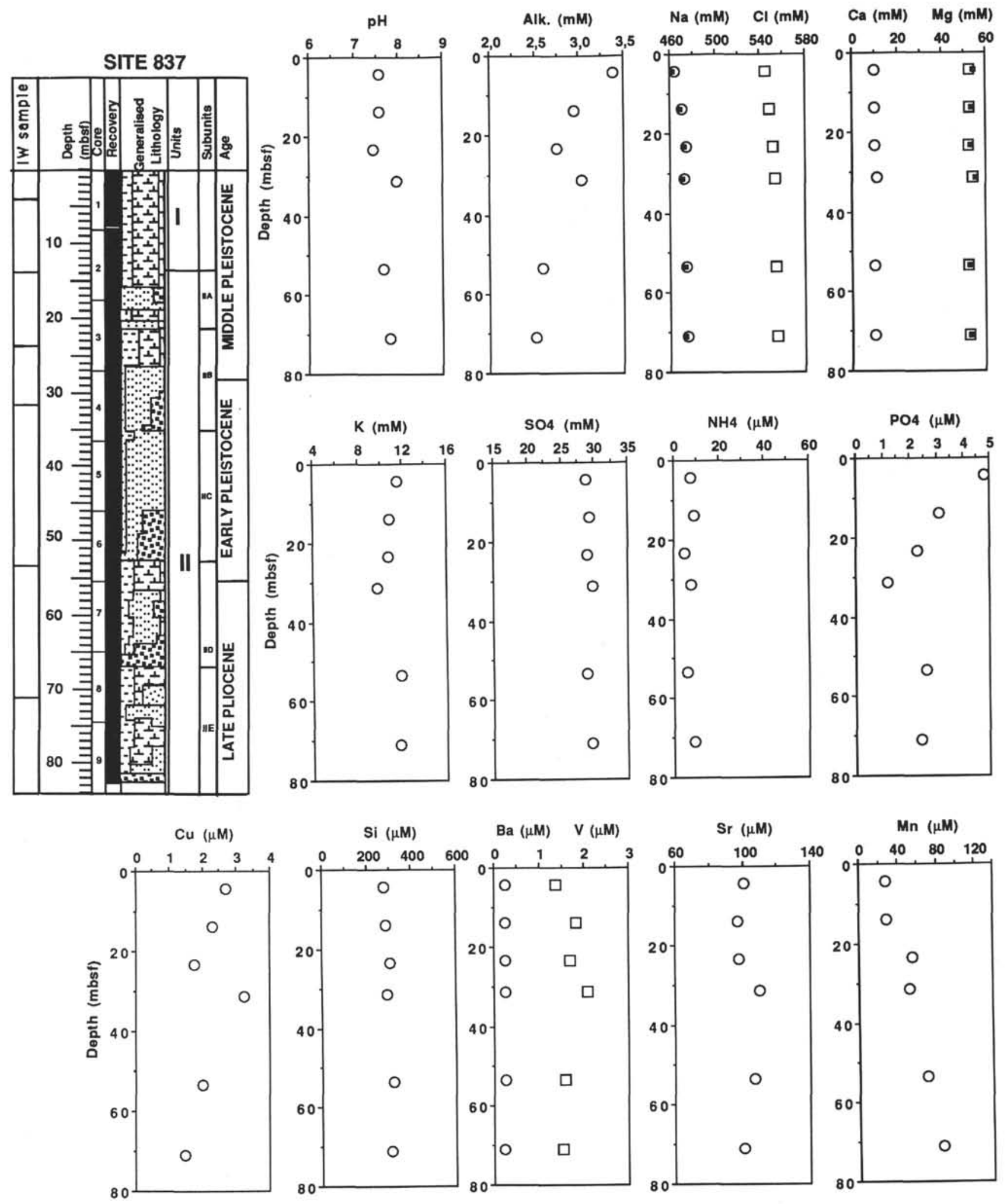

Figure 4. Lithologic summary column and interstitial water chemistry, Site 837. 


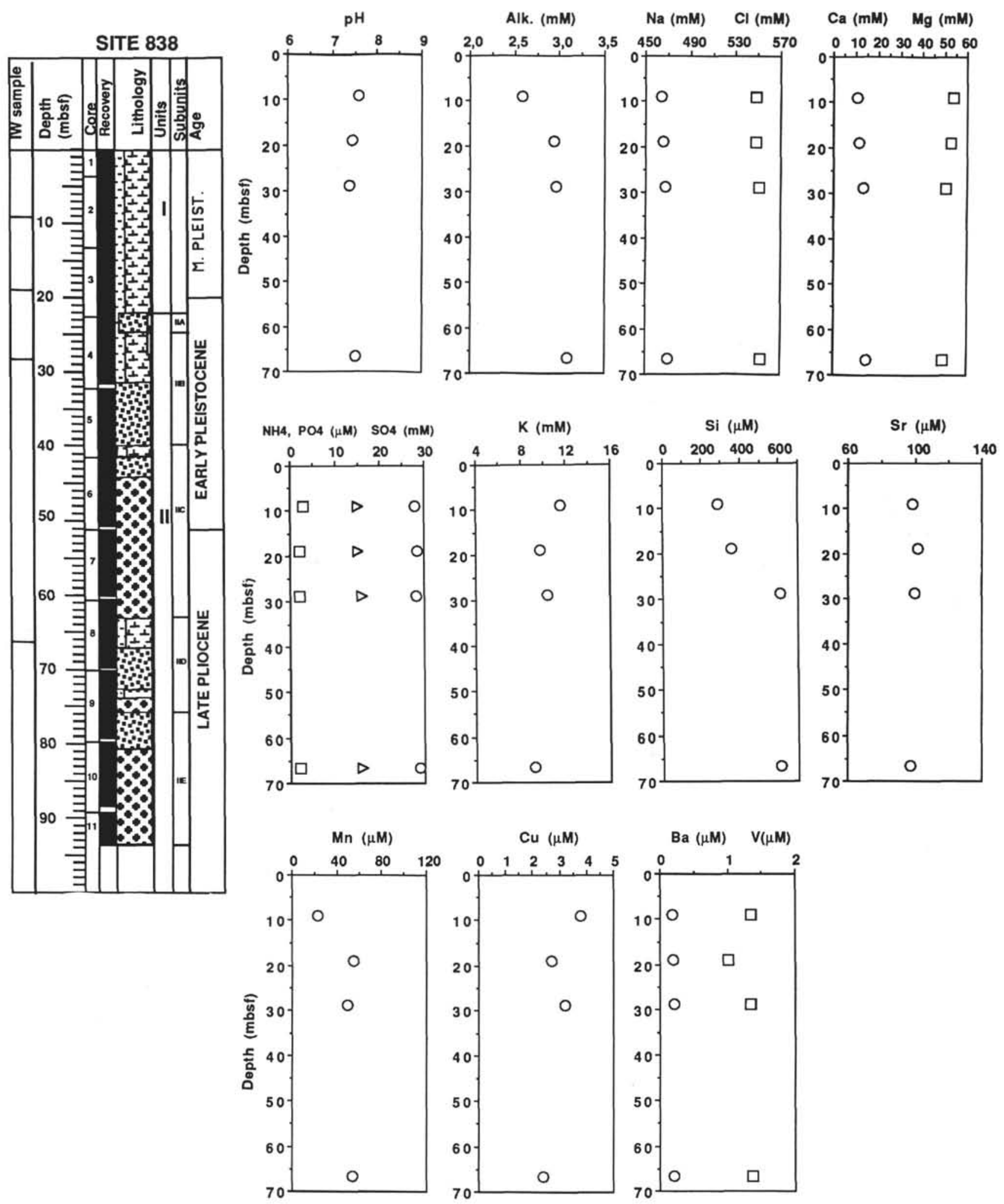

Figure 5. Lithologic summary column and interstitial water chemistry, Site 838 . 
A total of seven interstitial water samples were collected. Samples were taken from every core in the uppermost $31 \mathrm{mbsf}$. Below this depth, samples were taken every second core.

Chloride, sodium, calcium, magnesium, potassium, sulfate, and strontium concentrations are indistinguishable from average seawater concentrations (Fig. 6) and are comparable with those obtained in Holes $834 \mathrm{~A}$ through $837 \mathrm{~A}$.

As for the other Leg 135 sites, values of ammonia and phosphate concentrations in interstitial water samples from Hole 839A are very low and consistent with the fairly uniform sulfate data.

Silica, strontium, barium, and vanadium concentrations are characterized by nearly uniform values from the mud line to the bottom of the sedimentary column.

The manganese concentration-depth profile is comparable with those obtained at Sites $834,835,837$, and 838. Manganese concentrations increase with depth, reaching a maximum of $88 \mu \mathrm{M}$ at 48.5 mbsf. Below this manganese maximum, the concentrations decrease to value of $21 \mu \mathrm{M}$ at the base of Unit II. The copper concentrationdepth profile at Site 839 shows the same trend as the manganese profile, with a copper maximum of $3.12 \mu \mathrm{M}$ at $48.5 \mathrm{mbsf}$ followed by a decrease in copper concentration below this depth.

\section{DISCUSSION}

At all sites, the main features revealed by the interstitial water chemistry data are the extremely low gradients in the concentrationdepth profiles of the major chemical components (sodium, calcium, magnesium, potassium, chloride, and sulfate). This feature suggests that diagenesis has a negligible effect upon interstitial water composition in the Lau Basin. At numerous DSDP and ODP sites, alteration of the upper crustal basalts and of volcanogenic sediments into clays and zeolites leads to a depletion in dissolved magnesium, potassium, sodium, sulfate, and alkalinity and an enrichment in calcium (Kastner and Gieskes, 1976; McDuff, 1981; Gieskes et al., 1990). However. the occurrence of zeolites (phillipsite, analcime) and Fe-Mn-rich clays in the sedimentary column at Sites 834-839 probably reflect alteration of the volcanogenic material in the sediment of the Lau Basin (Blanc, 1992, this volume). Diagenetic processes cannot, therefore, be ruled out. We postulate that the low concentration gradients recorded by the major components suggest an open system for local seawater circulation throughout the sedimentary column. This hypothesis seems to be supported by the low downhole temperature gradients, which range between $0.7^{\circ}$ and $8.7^{\circ} \mathrm{C} / 100 \mathrm{~m}$ (Parson, Hawkins, Allan, et al., 1992).

The calculated heat-flow values, ranging between 9.3 and 50.6 $\mathrm{mW} / \mathrm{m}^{2}$, are much lower than the theoretical heat-flow values of 175 to $200 \mathrm{~mW} / \mathrm{m}^{2}$ predicted for young oceanic crust (Anderson et al., 1977). The chemical and thermal gradients suggest that fluid flow exchanges between sediment and seawater occur locally, and that fluid circulation in the backarc is sufficient to dissipate large amounts of heat. Similar chemical results were obtained on the flanks of the Galapagos Spreading Center in a low heat-flow area (Maris et al., 1984; Becker and Von Herzen, 1983; Baker et al., 1991). Considering that the small changes in $\mathrm{Ca}$ have been most directly related to the alteration of the volcanogenic material in the sediment or underlying basalts, the concentration of calcium as a function of depth for the entire data set of the Lau Basin sites reveals information about the fluid flow pathways (Fig. 7). These Ca profiles exhibit a systematic trend with a slight increase in calcium in the upper part of the sedimentary columns. Toward the bottom of the sedimentary cover, a decrease in the interstitial water calcium concentration was observed at Sites $834,835,837$, and 839.

At Site 838 , below $30 \mathrm{mbsf}$, the Ca concentration gradient is lower than observed above. Note that the maximum change in calcium concentration is recorded in Hole 838A, which also yields the highest temperature gradient. Furthermore, small but significant magnesium and potassium anomalies are linearly correlated to the calcium anoma- lies in this hole, indicating the conservative behavior of these elements in the sedimentary column. We postulate that these features can be related to two major processes that probably varied in intensity, space, and time: (1) alteration of the volcanogenic material involving diffusive transport between basement rock and overlying seawater and (2) advection of seawater at the boundary between hemipelagic sediments and basaltic basement (Sites 834-837) or indurated volcaniclastic sediments (Sites 838 and 839). In-situ reactions of volcanogenic sediments into clays and zeolites have probably worked in the past, but they did not affect the present major element concentration-depth profiles.

Trace metals such as manganese and copper are more useful than major elements for discriminating advection effects and diffusion processes caused by the interstitial water-solid phase exchanges. This is clearly shown in the general diagram of Figure 8, in which manganese concentrations are plotted vs. depth. At all sites, manganese increases with depth and manganese maxima occur within the hemipelagic sediments. At Sites $834,835,838$, and 839 , interstitial water manganese gradients decrease below these maxima, with manganese concentrations reaching the lowest values toward the bottom of the holes, where hemipelagic sediments are characterized by high portions of volcanogenic sediments. We postulate that the variation in the manganese concentration data probably results from seawater-solid interactions causing a manganese increase with depth in the past as well as from a dilution effect that caused an interstitial water manganese decrease more recently in the lower part of the sedimentary cover. However, at Site 837 , the deepest sample analyzed shows the highest manganese concentration in this hole. This could be related either to a higher manganese release by diagenetic processes or to a diluting downwelling flow located in the deeper horizon of the hemipelagic sedimentary columns. All the copper concentration-depth profiles also show a slight copper decrease in the deeper part of the holes (Fig. 8) and, therefore, support the assumption of a diluting downwelling flow toward the bottom of the sedimentary column. Conversely to the manganese profiles, the high copper concentrations determined at the top of Holes 834A, $836 \mathrm{~A}, 837 \mathrm{~A}, 838 \mathrm{~A}$, and $839 \mathrm{~A}$ suggest that diagenetic processes removed copper from the solid phases. However, the copper concentration of $1.92 \mu \mathrm{M}$ detected at $6.0 \mathrm{mbsf}$ in Hole $835 \mathrm{~A}$ seems to indicate a small exchange with seawater in the upper part of this hole.

The relative uniform patterns of the concentration-depth profiles suggest that molecular diffusion through the sedimentary column is probably responsible for the mixing between the two end-members. They are the interstitial water initially affected by the diagenetic processes and the diluting downwelling flow of seawater. The seawater probably circulates through structural pathways bounding the elongated sub-basins of the Lau Basin, and its initial chemical composition is probably slightly modified during its downward advection.

Advection of seawater at the hemipelagic sediment/volcanogenic basement boundary is also supported by the strontium concentration data and the preliminary results of strontium isotope measurements on interstitial waters (Fig. 9). The strontium concentration-depth profiles at Sites 834 and 835 show patterns similar to those of the manganese data sets. The relation among the interstitial water strontium concentrations, ${ }^{87} \mathrm{Sr} /{ }^{86} \mathrm{Sr}$ isotopic composition values, and depth (at Site 835) suggests that volcanogenic strontium is released during alterations that lower the strontium isotope ratios. In the sedimentary column at Site 835 , carbonate content ranges from $50 \%$ to $70 \%$, and predominantly originated from biogenic tests having a radiogenic strontium signature close to that of contemporaneous seawater. Thus, the dissolutionrecrystallization processes of biogenic tests may explain the increase in interstitial water strontium concentrations and, probably, helped limit the lowering of the strontium isotopic signature of the interstitial water from that of the ancient seawater. Therefore, the slight deviation of the strontium isotope ratios from contemporaneous water values more probably reflects volcanic material alteration in this hole.

However, diagenetic processes cannot explain the ${ }^{87} \mathrm{Sr} /{ }^{86} \mathrm{Sr}$ ratio determined at 148.5 mbsf, which is comparable with the present ${ }^{87} \mathrm{Sr} /{ }^{86} \mathrm{Sr}$ seawater ratio, and higher than that of Pliocene seawater. 

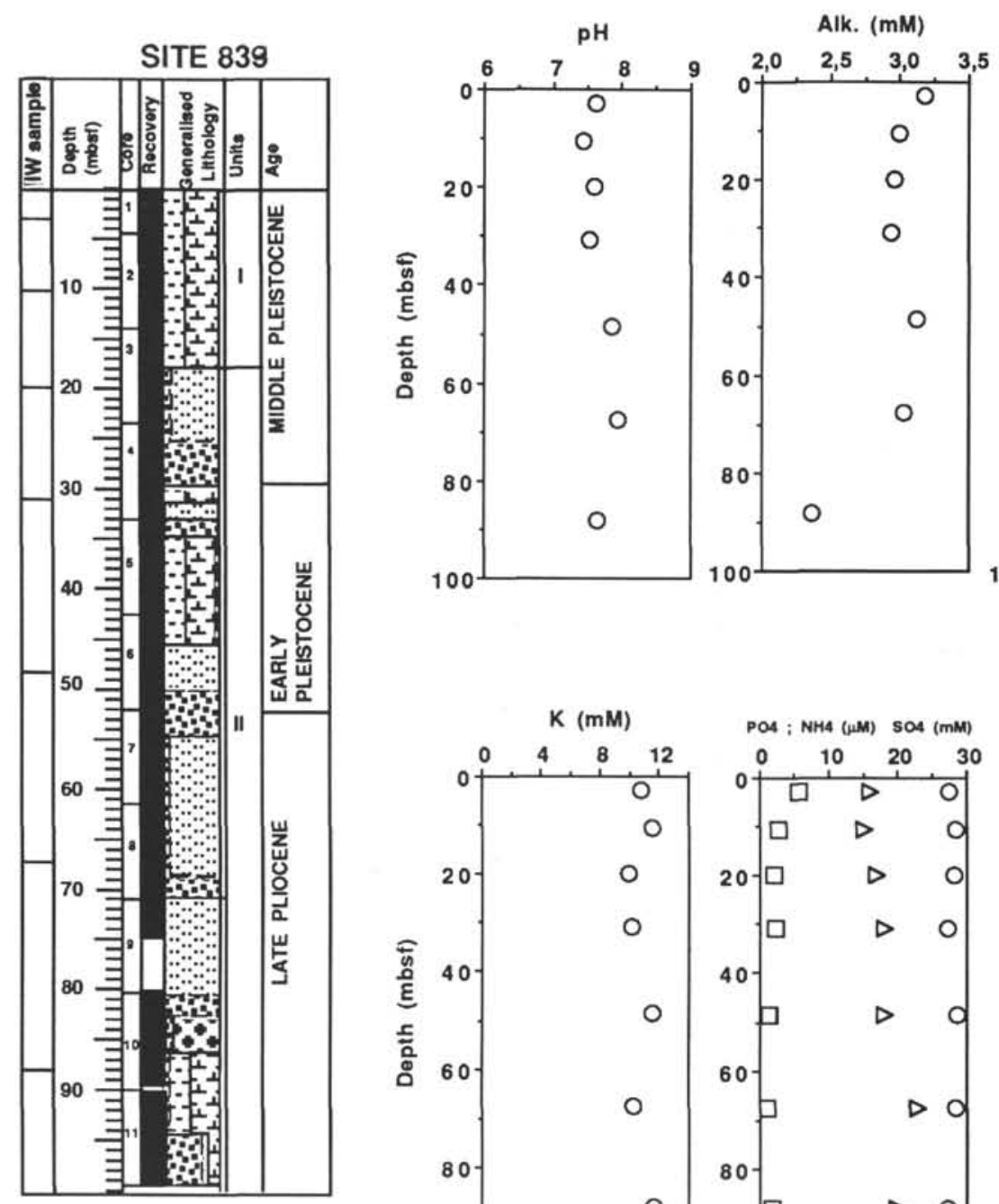

$\mathrm{Na}(\mathrm{mM}) \mathrm{Cl}(\mathrm{mM})$

$\mathrm{Ca}(\mathrm{mM}) \mathrm{Mg}(\mathrm{mM})$

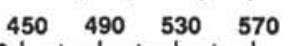
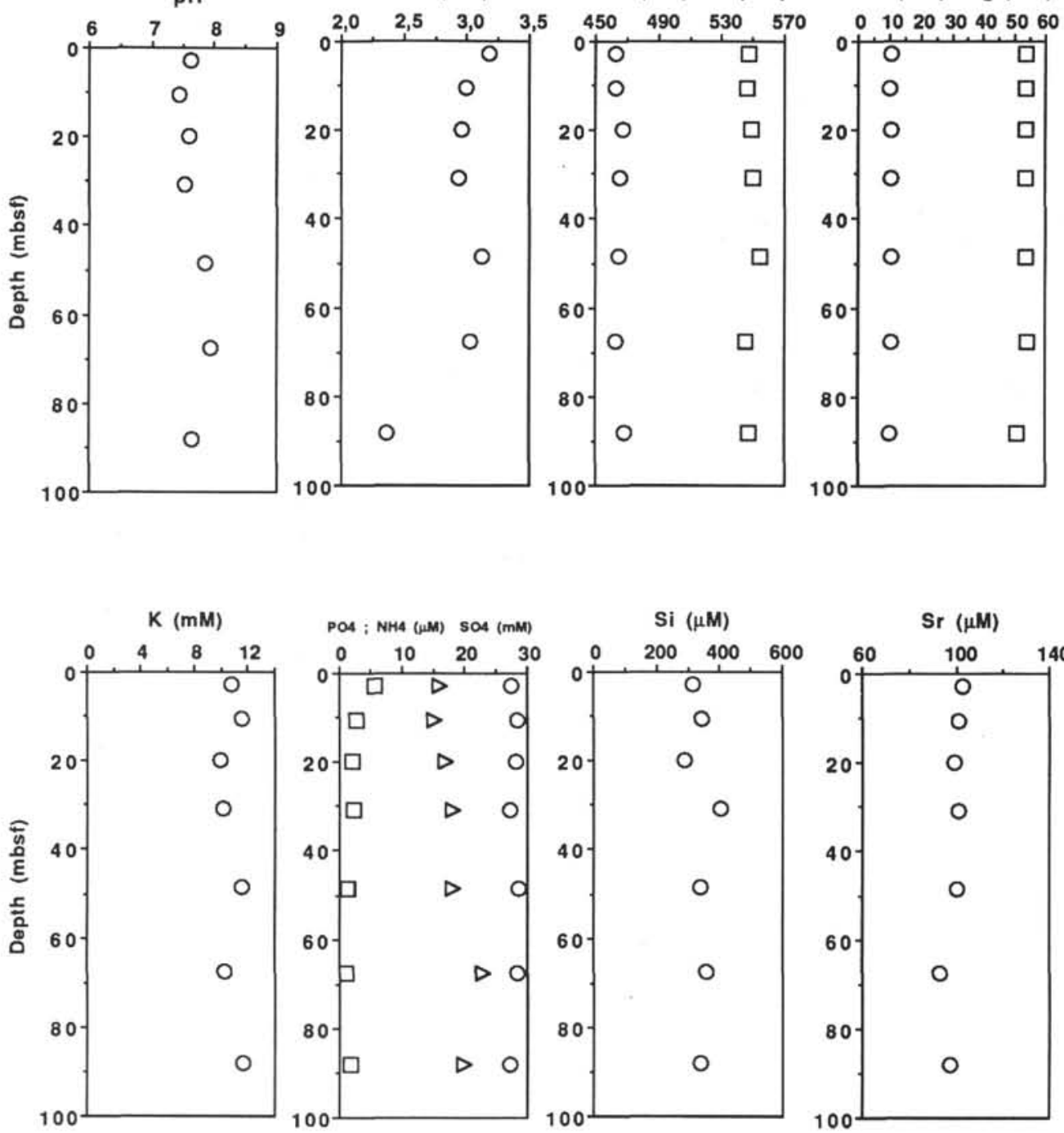

$\begin{array}{cccc}\text { PO4 ; NH4 }(\mu \mathrm{M}) & \text { SO4 } & \text { (mM) } \\ 0 & 10 & 20 & 30\end{array}$
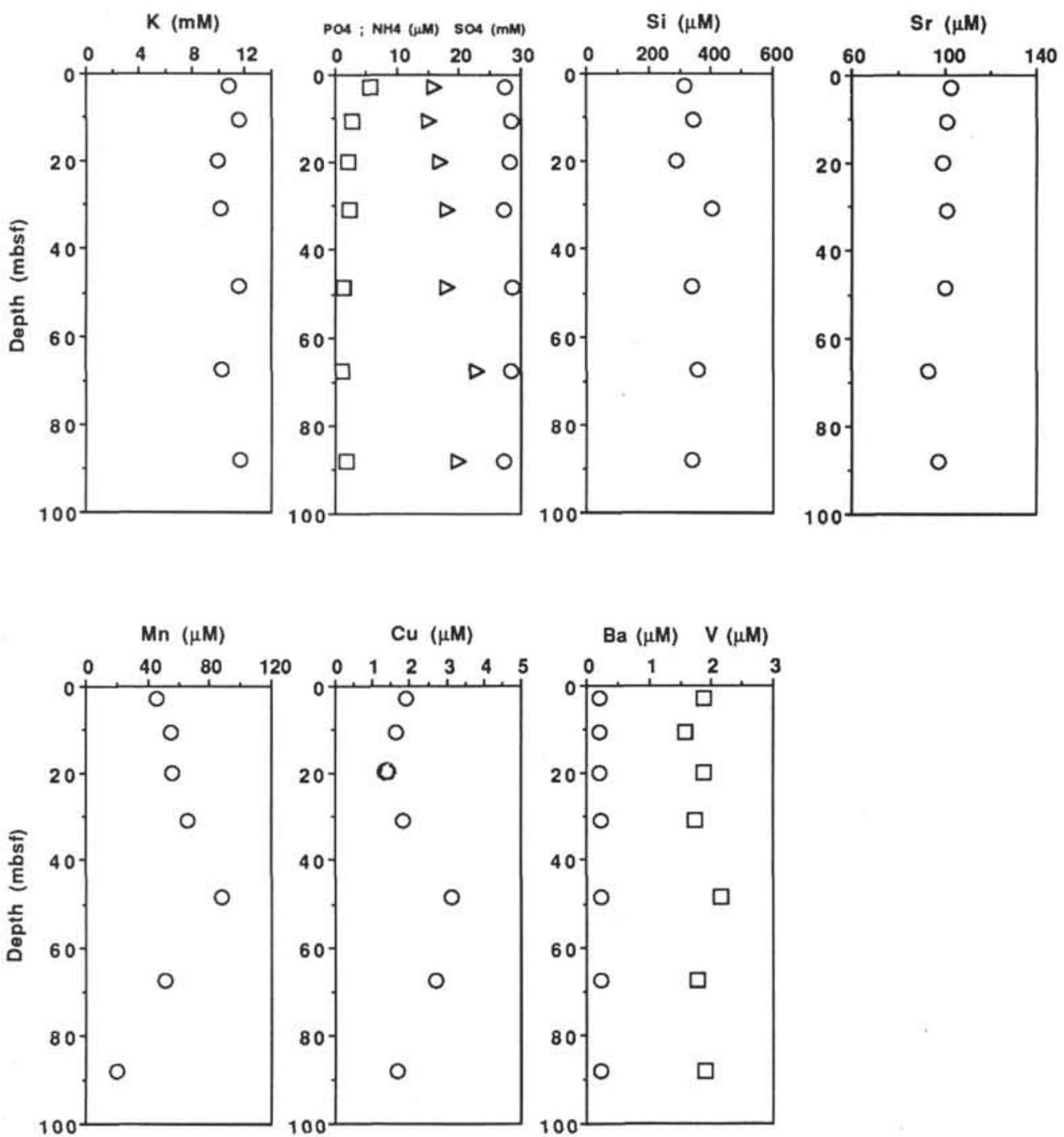

Figure 6. Lithologic summary column and interstitial water chemistry, Site 839. 


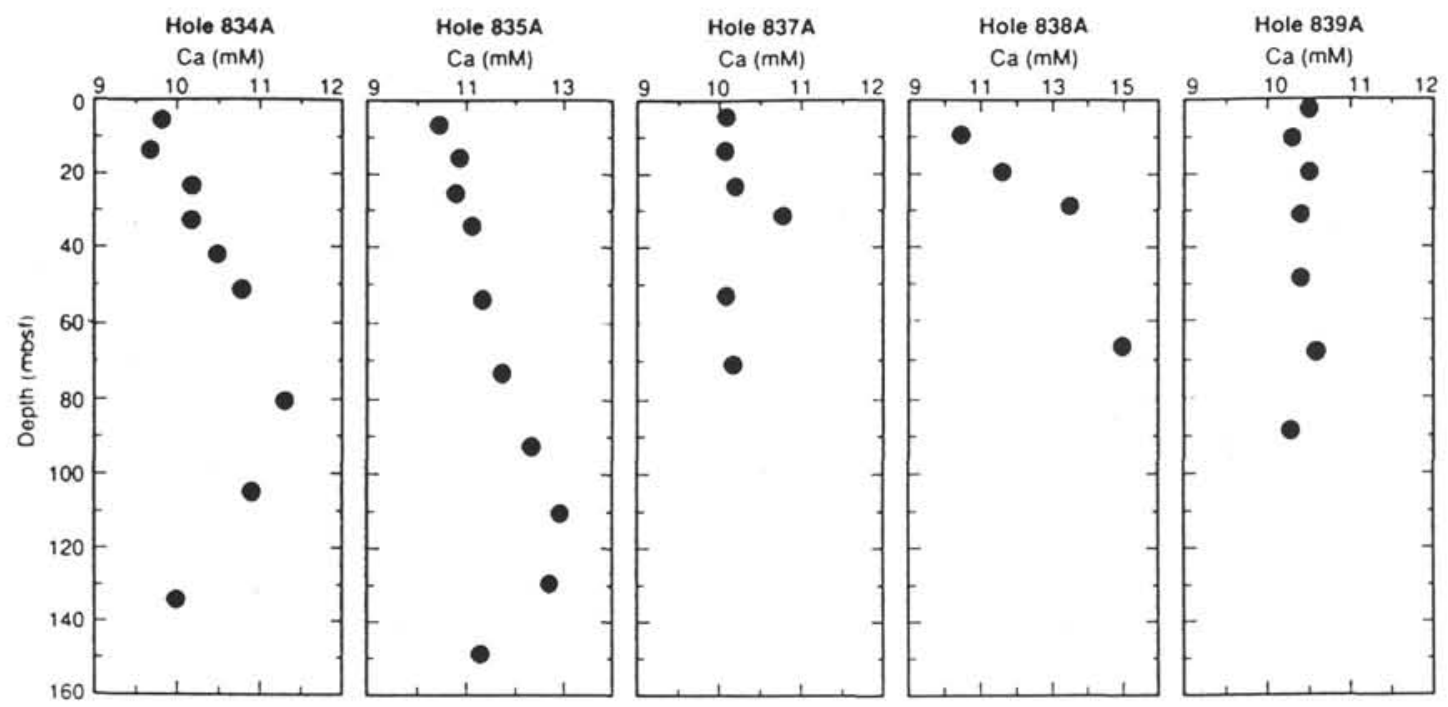

Figure 7. Geochemical profiles for dissolved calcium at the Lau Basin Leg 135 sites.

$\mathrm{Cu}(\mu \mathrm{M})$

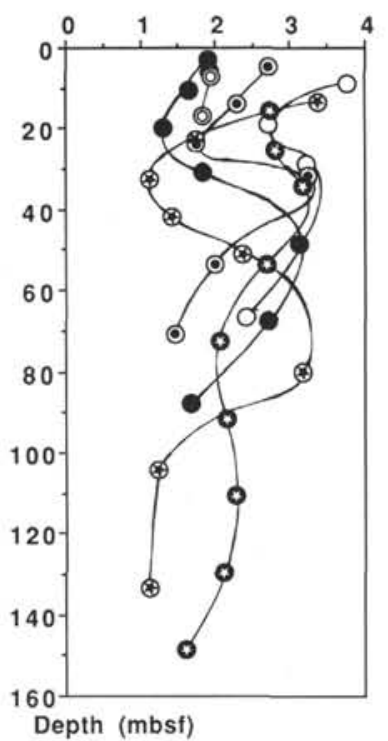

$M n(\mu M)$

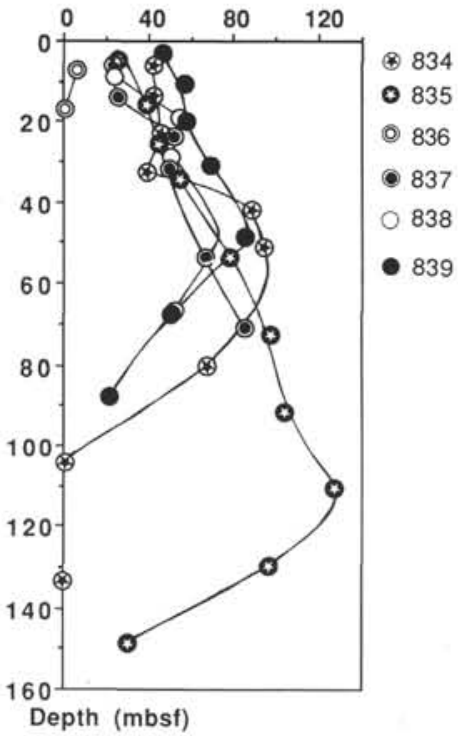

Figure 8. Generalized composite of copper and manganese concentrationdepth profiles from Sites 834-839.

This value can be best understood in terms of the recent downward advection of young seawater through localized pathways at the hemipelagic sediment/basalt basement boundaries. This circulation seems to be aided by the occurrence of permeable volcanic material overlying basement, and by the horst-graben seafloor topography across the western Lau Basin, which probably results from tectonic extension of the backarc Lau Basin. Structural studies of the drilling sites indicate that tectonic activity during the period of sediment deposition is poorly recorded in the sedimentary column (Parson, Hawkins, Allan, et al., 1992). This suggests that the downwelling flow could be essentially located through the major normal faults that bound the studied basins, as proposed in Figure 10 for the basin in which Hole $835 \mathrm{~A}$ was drilled. This downwelling flow is a plausible contributor to the water recharge of the present hydrothermal system associated with the Lau spreading centers.
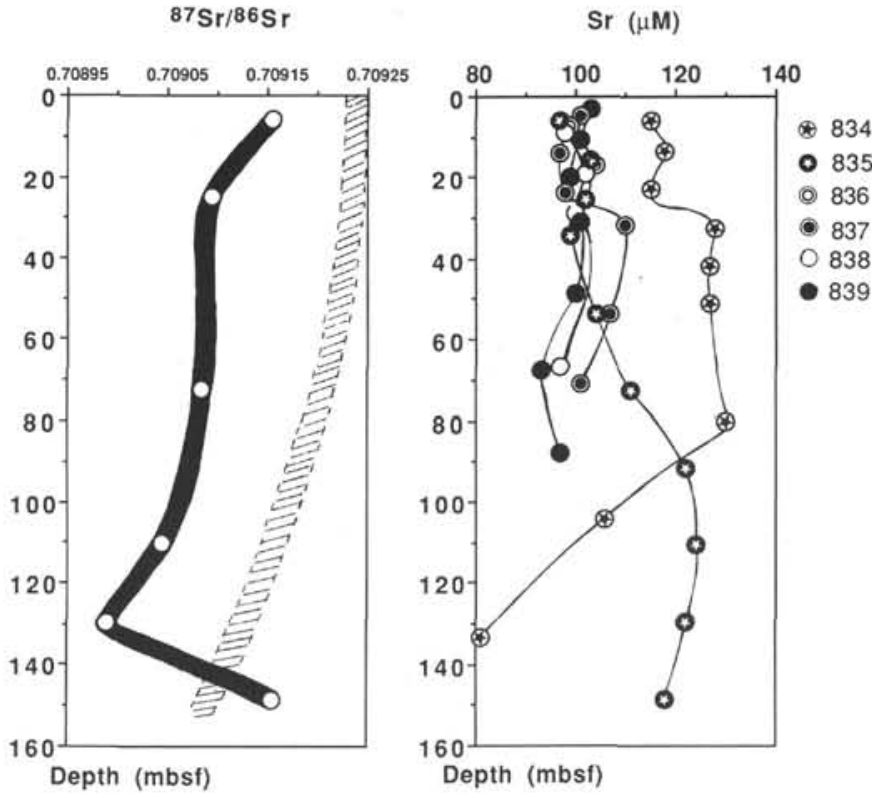

Figure $9 .{ }^{87} \mathrm{Sr} /{ }^{86} \mathrm{Sr}$ of dissolved strontium of Site 835 . Shaded zone represents contemporaneous seawater range. Generalized composite of strontium concentration-depth profiles from Sites 834-839.

\section{CONCLUSION}

Studies of the chemical composition of interstitial waters from sediments recovered at the drilling sites cored during Leg 135 in the backarc Lau basin revealed two major features explaining the concentration-depth profiles of the constituents: (1) a very low gradient of the major chemical constituents in the sedimentary columns, and (2) a systematic decrease in calcium, strontium, manganese, and copper concentrations toward the bottom of the sedimentary covers. These features suggest that the sedimentary system is probably recharged by a downwelling flow of young seawater along the major structural pathways bounding the elongated sub-basins of the Lau basin. This recent seawater input at the sediment/basalt boundaries affected the diagenetic chemical signature of the pore water, first by dilution at the base of the sedimentary column, and second by 


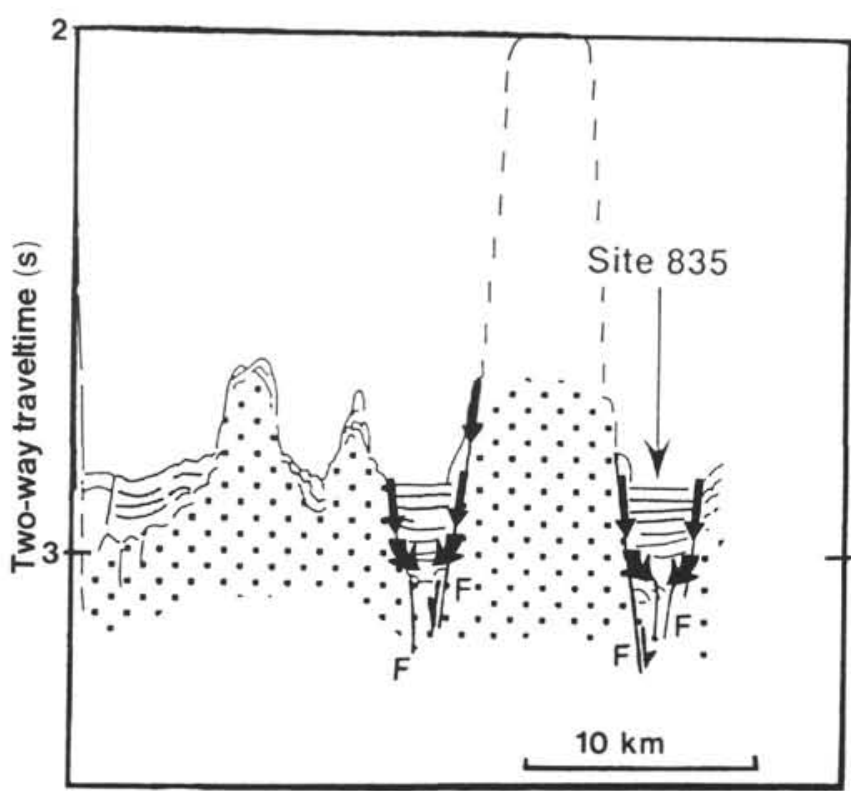

Figure 10. Suggested pathways of seawater migration in the narrow elongated basins located on the flanks of the Lau Basin spreading centers. Line-drawing interpretation at Site 835 from Parson, Hawkins, Allan, et al. (1992). Arrows represent the downwelling flow along normal faults $(F)$ that bound the sedimentary basins.

diffusive transport acting within the whole bulk sediment. This hypothesis is also supported by the strontium isotope data obtained at Site 835 and by heat-flow and physical properties data (Parson, Hawkins, Allan, et al., 1992).

\section{ACKNOWLEDGMENTS}

G.B. would like to thank J. Samuel and R. Rouault (Centre de Géochimie de la Surface, C.G.S.) for their analytical determinations of major and trace chemical composition. G.B. would like to thank the Leg 135 Scientific Party and Technical and Operating Staff. J. Allan, J. Erzinger, and P.A. Baker are also thanked for reviewing early drafts. This research was supported by INSU Grant GEO 913922 , "Geosciences marines" (GB).

\section{REFERENCES}

Anderson, R.N., Langseth, M.G., and Sclater, J.G., 1977. The mechanisms of heat transfer through the floor of the Indian Ocean. J. Geophys. Res., $82: 3391-3409$.

Auzende, J.M., et al., 1989. Geological setting of an active hydrothermal site: preliminary results of the Starmer I cruise of the submersible Nautile in the North Fiji basin. C. R. Acad. Sci. Ser. 2, 309:1787-1795.

Baker, P.A., Stout, P.M., Kastner, M., and Elderfield, H., 1991. Large-scale lateral advection of seawater through oceanic crust in the central equatorial Pacific. Earth Planet. Sci. Lett., 105:522-533.

Becker, K., and Von Herzen, R.P., 1983. Heat transfer through the sediments of the Mounds Hydrothermal area, Galapagos Spreading Center at $86^{\circ} \mathrm{W}$. J. Geophys. Res., 88:995-1008.

Bertine, K.K., and Keene, J.B., 1975. Submarine barite-opal rocks of hydrothermal origin. Sciences, 188:150-152.

Both, R., et al., 1986. Hydrothermal chimneys and associated fauna in the Manus back-arc basin. Papua New Guinea. Eos, 67:489-490.

Broecker, W.S., and Peng, T.-H., 1982. Tracers in the Sea: Palisades, NY (Eldigio Press).

\footnotetext{
Abbreviations for names of organizations and publication titles in ODP reference lists follow the style given in Chemical Abstracts Service Source Index (published by American Chemical Society).
}

Claypool, G.E., and Kaplan, I.R., 1974. The origin and distribution of methane in marine sediments. In Kaplan, I.R. (Ed.), Natural Gases in Marine Sediments: New York (Plenum), 99-140.

Craig, H., Horibe, Y., Farley, K.A., Welhan, J.A., Kim, K.R., and Hey, R.N., 1987. Hydrothermal vents in the Mariana Trough: results of the first Alvin dives: Eos, 68:1531.

Fouquet, Y., Charlou, J.L., Donval, J.P., Foucher, J.P., Harmegnies, F., Pelle, H., von Stackelberg, U., Wiedicke, M., Erzinger, J., Herzig, P., Muehe, H., Soakai, S., and Whitechurch, H., 1990. Hydrothermal activity in the Lau Basin: first results from the Nautilau cruise. Eos. 71:678-679.

Fouquet, Y., von Stackelberg, U.. and Charlou, J.L., Donval, J.P., Foucher, J.P.. Erzinger, J.. Herzig, P., Mühe, R., Wiedicke, M., Soakai, S., and Whitechurch, H., 1991. Hydrothermal activity in the Lau back-arc basin: sulfides and water chemistry. Geology, 19:303-306.

Gieskes, J.M., 1973. Interstitial water studies, Leg 15: alkalinity, pH, Mg, Ca, $\mathrm{Si}, \mathrm{PO}_{4}$, and $\mathrm{NH}_{4}$. In Heezen, B.C., MacGregor, I.D., et al., Init. Repts. DSDP, 20: Washington (U.S. Govt. Printing Office), 813-829.

- 1974. Interstitial water studies, Leg 25, In Simpson, E.S.W., Schlich, R., et al., Init. Repts. DSDP, 25: Washington (U.S. Govt. Printing Office), 361-394.

1983. The chemistry of interstitial waters of deep-sea sediments: interpretation of deep-sea drilling data. In Riley, J.P., and Chester, R. (Eds.), Chemical Oceanography (Vol. 8): London (Academic Press), 222-269.

Gieskes, J.M., Blanc, G., Vrolijk, P., Elderfield, H., and Barnes, R., 1990. Interstitial water chemistry-major constituents. In Moore, J.C., Mascle, A.,et al., Proc. ODP. Sci. Results, 110: College Station, TX (Ocean Drilling Program), 155-178.

Gieskes, J.M., Elderfield, H., and Palmer, M.R., 1986. Strontium and its isotopic composition in interstitial waters of marine carbonate sediments. Earth Planet. Sci. Lett., 77:229-235.

Gieskes, J.M., Kastner. M., and Warner, T.B., 1975. Evidence for extensive diagenesis, Madagascar Basin, Deep Sea Drilling Site 245. Geochim. Cosmochim. Acta, 39:1385-1393.

Gieskes, J.M., and Lawrence, J.R., 1981. Alteration of volcanic matter in deep-sea sediments: evidence from the chemical composition of interstitial waters from deep-sea drilling cores. Geochim. Cosmochim. Acta, 45:1687-1703.

Gieskes, J.M., and Peretsman, G., 1986. Water chemistry procedures aboard JOIDES Resolution-some comments. ODP Tech. Note, 5.

Halbach, P., et al., 1989. Probable modern analogue of Kuroko-type massive sulphide deposits in the Okinawa Trough back-arc basin. Nature, 338:496-499.

Hawkins, J.W., and Helu, S., 1986. Polymetallic sulphide deposit from "blacksmoker" chimney: Lau Basin. Eos, 67:378.

Kastner, M., and Gieskes, J.M., 1976. Interstitial water profiles and sites of diagenetic reactions, Leg 35, DSDP, Bellingshausen Abyssal Plain. Earth Planet. Sci. Lett., 33:11-20.

Manheim. F.T., and Sayles, F.L., 1974. Composition and origin of interstitial waters of marine sediments based on deep sea drill cores. In Goldberg, E.D. (Ed.), The Sea (Vol. 5): New York (Wiley Interscience), 527-568.

Maris, C.R.P., Bender. M.L., Froelich, P.N., Barnes, R., and Luedtke, N.A., 1984. Chemical evidence for advection of hydrothermal solutions in the sediments of the Galapagos Mounds Hydrothermal Field. Geochim. Cosmochim. Acta, 48:2331-2346.

McDuff, R.E., 1981. Major cation gradients in DSDP interstitial waters: the role of diffusive exchange between seawater and upper ocean crust. Geochim. Cosmochim. Acta, 45:1705-1713.

McDuff, R.E., and Gieskes, J.M., 1976. Calcium and magnesium profiles in DSDP interstitial waters: diffusion or reaction? Earth Planet. Sci. Lett., $33: 1-10$.

Parson, L., Hawkins, J., Allan, J., et al., 1992. Proc. ODP, Init. Repts., 135: College Station, TX (Ocean Drilling Program).

Rosenfeld, J.K., 1979. Ammonium adsorption in nearshore anoxic sediments. Limnol. Oceanogr., 24:356-364.

von Breymann, M.T., and Suess, E., 1988. Magnesium in the marine environment: $\mathrm{Mg}-\mathrm{NH}_{4}$ ion exchange. Chem. Geol., 70:359-371.

von Stackelberg, U., and Shipboard Scientific Party, 1985. Hydrothermal sulphide deposits in back-arc spreading centres in the southwest Pacific. Bundesanst. Geowiss. Rohstoffe Circ., 2:3-14.

1988. Active hydrothermalism in the Lau back-arc basin (SW Pacific): first results from the Sonne 48 cruise (1987). Mar. Min., 7:431-442.

von Stackelberg, U., and von Rad, U., 1992. Geological evolution and hydrothermal activity in the Lau and North Fiji basin. Geol. Jahrb., D92:629.

Date of initial receipt: 1 December 1992

Date of acceptance: 22 March 1993

Ms 135SR-123 